\title{
METALINGUISTIC ACTIVITY, HUMOR AND SOCIAL COMPETENCE IN CLASSROOM DISCOURSE ${ }^{1}$
}

\author{
David Poveda
}

\begin{abstract}
This paper examines the role that humor plays during an episode of classroom interaction. Using concepts derived from the ethnography of communication and interactional sociolinguistics, it analyzes activity during a metalinguistic event in a kindergarten classroom and argues that verbal humor, in itself a form of metalinguistic activity, plays a crucial role in the modulation of children's face demands. The analysis also shows how humor is the result of the shared history of participants. The findings highlight the importance of considering emergent and improvised goals during classroom discourse that go beyond the prescribed curriculum.
\end{abstract}

Keywords: Classroom discourse, Humor, Metalinguistic Development, Microethnography.

\section{Introduction}

Classrooms are sophisticated contexts that require students to display elaborate sociocognitive skills to participate successfully in them. Ideas such as academic task structure and social participation structure (Erickson 1982), the translation of general politeness strategies in classroom conversation (Cazden 1988) and all the widely described scaffolding processes (e.g. Newman, Griffin and Cole 1989) capture the simultaneous attention that students and teachers pay to, among other things: (a) the logic of the content matter being learned, (b) the structure of the classroom tasks through which this content is taught, (c) the public display of knowledge and how this display might affect the social image of its 'holder', (d) the inferences that participants build from each other's actions, and (e) the cues that these same participants provide to aid their inferential processes.

Certain situations and knowledge domains allow for a more complex interplay between the academic and socio-emotional demands of classroom participation. Metalinguistic development, understood here as the growing ability to reflect on and manipulate independently from each other different components of the linguistic system, may be considered such a domain for several reasons. First, metalinguistic knowledge plays an important role in the curriculum of many kindergarten and early

${ }^{1}$ I would like to thank Susana Tomé for her assistance in the preparation of the video-captured photographs and the anonymous reviewer for her suggestions and corrections to the original manuscript. 
primary school classrooms as it is related to literacy learning (Snow, Burns and Griffin 1998). Second, under the rubric of metalinguistic ability we find a number of skills that include internal self-reflective process such as metasyntactic or metaphonological skills (Gombert 1992; Tunmer, Pratt and Herriman 1984; Karmiloff-Smith 1992), word to world relationships such as metasemantic development (Gombert 1992; Piaget 1984; Osherson and Markman 1975) or socio-interactive activities such as verbal play and linguistic humor (Cazden 1992; Ely and McCabe 1994). As a result, classroom metalinguistic tasks can activate simultaneously children's cognitive, linguistic, social and interpersonal skills and produce situations in which the identities of students and teachers are construed in elaborate ways.

This paper examines an episode of classroom activity that illustrates the interplay between socio-emotional concerns and the manipulation of different metalinguistic dimensions. The segment to be examined is part of a frequent activity in the classroom that 'officially' centers on solving metasyntactic and metasemantic tasks. However, during the activity, the teacher, the group of children solving the task and the rest of the class incorporate humor through language play. This is done to confront some of the problems that the group working on the task is having and, as a result, the face threatening situation for the group is mitigated. In the process, new aspects of language manipulation are incorporated into the activity expanding the metalinguistic components explored during this classroom episode. With this analysis I hope to provide support for two theoretical propositions. First, that we should adopt a broad view of the processes and mechanisms involved in metalinguistic development versus an artificially and experimentally segmented view of this linguistic domain (cf. Gombert 1992; Tunmer, Pratt and Herriman 1984). This should be further considered as a theoretical tenet, since it is this less restrictive understanding of metalinguistic knowledge to which participants seem to orient themselves in face-to-face interaction. Second, that the outcomes we might find during episodes of classroom interaction should be understood in 'historical' perspective since it is precisely the previous shared history of participants that allows for the efficient improvisation and development of emergent goals.

\section{Metalinguistic skills, conversational humor and face: Convergences in classroom interaction}

Developmental and educational researchers have paid considerable attention to metalinguistic development because it is part of general language learning and has been related to literacy acquisition. There is an established line of research that affirms phonological awareness to be deeply intertwined with decoding skills during the early stages of learning to read (Rohl and Pratt 1995; Snow, Burns and Griffin 1998; Sebastián and Maldonado 1998). There is also an emerging trend of research that relates metasyntactic development to reading comprehension in the later reading years (Nation and Snowling 2000). Both these strands of research define metalinguistic ability in strict terms as an identifiable component that researchers can isolate and measure in experimental tasks. 
Studies that focus on the metalinguistic nature of linguistic humor might also adopt this restrictive-experimental approach (e.g. Ashkenazi and Ravid 1998). However, verbal humor and verbal play have been areas where the nature of metalinguistic knowledge has been broadened and the methodologies employed to study them have relied on observational and ethnographic approaches (e.g. Cazden 1992; Ely and McCabe 1994; Kirschenblatt-Gimblett 1979). Ethnographic research admits that being able to explain why a particular utterance contains an incongruence or expansion of its usual referential or instrumental function may be a cognitive task, but it also argues that seeing an utterance as 'funny' has more to do with the social and interactional uses of language than with the internal structure of the linguistic product. Examining verbal play from this perspective takes us to the second strand of concepts to be discussed.

Considering humor as a conversational phenomenon also means seeing humor as a situated practice that rests on the emergent understandings that participants coconstruct during conversation. Kotthoff $(1995,1998,1999)$ has examined extensively how humor develops during informal conversations among adult friends and sees it as an achievement that stems simultaneously from the shared history and identities of the group of friends and the contextualizing and coherence devices each participant displays during talk. She has also provided an elaboration of two very useful analytic tools to understand this process. First, Kotthoff proposes to think of keying, based on the classic notion of key in the ethnography of speaking (Hymes 1974; Bauman 1977), as an emergent achievement that "contributes to a specific text understanding" (defining text as ongoing discourse) (Kotthoff 1999: 126). Second, Kotthoff has stressed the functions that various contextualization cues (Gumperz 1992) play in this process. However, the focus is not on the use and function of a single class of linguistic or paralinguistic resource but on how a variety of resources can be used in the same episode to achieve similar pragmatic functions (i.e. key a story or event as humorous). To underscore this difference I will introduce the notion of contextualization move to describe one of several communicative acts that contribute to key ongoing conversation.

Humor in classroom interaction has received some attention. Walker and Adelman (1978) examine the role that humor plays in reducing the social distance between teachers and students and in the construction of classroom identities. Corsaro (1994) discusses the functions of humor and playful teasing by the teacher in the resolution of peer conflicts in an Italian pre-school classroom. These studies highlight the role that humor and variations in the key of classroom activity play in the type of alignments that are built between teachers and students in the class. Thinking in these terms leads to the last cluster of ideas to be discussed in this introduction.

Cazden (1988) has presented a general translation into classroom contexts of Brown and Levinson's classic politeness model. Brown and Levinson (1987) developed an ambitious framework that has generated much research and controversy with some criticisms also applying to the classroom version. For the purpose of this paper it is not necessary to delve into these problems or uptake all the implications of Brown and Levinson's model, since the main concern will be centered on describing some general features associated with the notion of face (cf. Goffman 1967).

In classroom interaction, children's social position and presumed competence (face) can be threatened by teachers (and peers) in two basic ways. First, children's actions in classrooms are often explicitly evaluated and this assessment might be 
negative (which threatens the need to be appreciated and positively valued - positive face). Second, teachers have considerable power to control, interrupt and redirect children's behavior inside schools (limiting children's freedom - negative face) (Cazden 1988). Under these circumstances participants have a repertory of interactional resources designed to mitigate or aggravate the face-threatening nature of many exchanges. Teachers can accompany their demands with a number of modulating devices (such as humor) or they can be explicitly on-record when they want to make clear the hierarchical order of the classroom (e.g. Tsai and Garcia 2000). On their part, students can also engage in a number of behaviors designed to avoid face-threatening exchanges (e.g. McDermott 1977), or, as we will see later, redefine the nature of their own actions and their subsequent interpretation.

What is relevant about this repertory is that it is displayed in interaction and is based more on participant's local assessments of the situation than on the properties ascribed to them by virtue of fixed roles (such as 'pupil' or 'teacher'). For example, a student might find a question from the teacher face threatening on the basis of his or her own ability to answer the question. Yet, often this conclusion will also be based on the student's assessment of the degree to which some, most or none of his or her classmates can answer correctly questions of the same type. This comparison can be made taking into consideration the most immediate previous activities, the histories of participants or even the future consequences of the student's actions. Furthermore, the interpretation of the consequences of certain public actions may be mediated by larger cultural values regarding how group relations should be maintained (e.g. Phillips 1972).

To recapitulate, the intersection of metalinguistic problems, face demands and conversational humor indicates that certain curricular tasks allow for a number of convergences between interactional, linguistic, emotional and cognitive processes. Children and teachers seek to establish and protect particular social identities in the classroom. Humor may be used as a resource in the maintenance of these identities, but humor may also be seen as a metalinguistic achievement. As a result, apparently aseptic language tasks may become important socio-emotional episodes in which children's pragmatic and metalinguistic competence is expanded in directions not foreseen in formal curricular objectives. After presenting the procedures of the study I discuss an example that illustrates how all these processes take place.

\section{Method}

The data for this paper were gathered as part of a larger ethnographic study of classroom interaction during three recurrent literacy events in a kindergarten classroom. Throughout the 1997-98 school-year field notes were taken several days a week during the full academic year and video-recordings of each speech event were made every other week. These recordings were transcribed and analyzed in depth. Also, all participants, the children and the teacher, were interviewed formally and informally.

The site of the study was a public primary school located in a working class district of the city of Madrid, Spain. The class, reflecting the demographics of the neighborhood and the socio-economic and ethnic segregation that is taking place between private and public schools, was ethnically heterogeneous (with several 
immigrant children, Spanish Gypsy children and Spanish non-Gypsy children) but socio-economically homogeneous (with parents ranging from unskilled to semi-skilled occupations). The 18 children ( 8 girls, 10 boys) were five years of age when the school year began and 13 of them turned six during the school year. The teacher, a woman in her mid-thirties, had many years of experience working in public schools of this same district.

\section{Managing multiple demands during the word train}

El tren de palabras 'the word train' was one of several language games presented in the classroom designed to teach literacy-related skills. This specific activity took place every two weeks and required the students to build sentences using cards with drawings taken to represent words - in this way, it is based on similar principles as the rebus books (Snow, Burns and Griffin 1998). These materials and the task are relatively well known in Spanish kindergarten and early primary classrooms thanks to the popular works of Spanish language therapists Monfort and Juárez (1996). In the 'standard' organization of the event the children were required to complete a number of steps. First, select cards from different stacks organized on a table. These stacks were based on grammatical categories: 'subject cards' in one pile, 'verb cards' in another pile, 'object cards' in a third pile and all 'functional word cards' (articles, quantifiers, adverbs, etc.) in a last pile. Second, organize these cards into sentences by hanging them from left to right on a rope that crossed the blackboard. The sentences could be offered by the teacher at the beginning of the task or they could be chosen by the child with some general guidelines (e.g. "write what you want for Christmas"). Third, once the sentence was put up and revised or corrected if necessary, the whole group read the sentence in a chorus three times: Once aloud, once clapping their hands as they read and a last time 'counting with their fingers' as they read.

The activity began with relatively simple sentences (e.g. 'Juan bebe agua' Juan drinks water built as BOY - MOUTH - GLASS OF WATER ${ }^{2}$ ) and became more complex as the year progressed by adding more cards, functional words and conventional spelling (e.g. 'Papá compra dos tortugas verdes' Daddy buys two green turtles built as PAPÁ - HAND WITH A COIN - 2 - A TURTLE - A GREEN DASH). Also, the participation structure experienced transformations throughout the school year. In the initial structure an individual student built the sentence, the teacher assisted and the rest of the class contributed to the final assessment and choral reading. Later in the year building a phrase became a group activity and the whole organization of the event as well as the available resources changed (as in the example below).

Formally, this activity is designed to promote writing skills such as oral word segmentation and print-sound relationships. The nature of the materials and the way they are used force the children to resolve a number of linguistic problems: (a) semantic problems since the drawing-word-referent relationship can have multiple mediations; (b) morphological problems since there may be variations in the 'reading' of each

${ }^{2}$ To differentiate the format of the materials being discussed I will use the following conventions: In lower case italics the sentence told and read orally, in capital letters a description of the drawing representing the word, in capital italics cards that use conventional writing. 
drawing and phrase in relation to gender or number, and (c) syntactic problems since stacks and drawings can be used in multiple ways. As I will discuss, all these formal resources can be used to improvise new language games and confront emergent social tasks during the word train.

The episode to be analyzed took place at the end of the school year. The teacher distributed a number of cards to each table in the classroom and asked the students at each table to build together a sentence with the cards. When they were finished, each group went to the blackboard, hung its sentence and did the final routine described above. The first three groups in the class were able to build and present their sentences without much difficulty. However, the last group seemed to have trouble building its sentence during the whole table-work segment of the session and was given several hints from the teacher during this time that the result might not be fully correct. The transcript below shows most of what happened when this last group of children went up to the blackboard to hang their sentence ${ }^{3}$ :

(1) Fragment of the word train (Spanish original)

((El grupo de niños ha puesto en la pizarra:))

BOCA - ZANAHORIA - 1 - LA - MULA

(...)

$1 \quad$ PAZ: a ver (1) bueno (1) vamos a leer todos juntoss (1)-shh (1) oye por cierto ((dirigiéndose al equipo)) ¿vosotros sabéis-este equipo? ¿eh? este equipo ¿lo que pone aquí? ((señalando el cartel $M U L A))$ ¿qué pone aquí?

ALU: $\quad$ XXX

PAZ: ¿lo habéis leído o no?

ALU: no

PAZ: ((baja el brazo)) ¿y entonces cómo [(vas a hacer la XXX)?

ALU:

(2)

[PLUMA ((de la clase))

PAZ: $\quad$ a ver ¿qué pone aquí? ((tapa $L A$ del cartel con la palma de la mano))

ALU: ((equipo a coro)) pluu-

PAZ:

LUI: $\quad$ mmuu ((del equipo))

$-(($ niega $))$

PAZ: $\quad(($ mueve la mano y tapa $M U))$ muu

SAL: ((del equipo))la-la muu-l-la

PAZ: ¿qué pone?

SAL: mula

3 The transcription symbols used in this paper are:

NAM: First three letters of the participant's name (pseudonyms).

(): $\quad$ Pause in seconds.

$=$ : $\quad$ Latching.

-: $\quad$ Interruption (self-other).

[ : $\quad$ Verbal overlap.

*: $\quad$ Simultaneous non-verbal action.

und: Prosody change (particular stress, direct speech, etc.).

CAP: Higher volume.

(): $\quad$ Possible transcription.

XXX: Non-transcribable fragment.

(()): Commentary.

(\&): Verbal and non-verbal action of the participants that continues across non-contiguous lines. 
PAZ: mula (1) pues no se=vamos a ver entonces qué pone aquí ((señala los carteles))

[come -zanahoria $=\quad$ una la mula $(\&)$

ALU: [come una- =zanahoria una la mula ((a coro, varios))

PAZ: (\&) ¿qué es esto? ((extrañada enfáticamente))

ALU: ((carcajadas toda la clase))

PAZ: ((señalando los carteles y agitando las manos)) ¿esto tiene sentido?

ALU: $\quad(($ a coro $))$ NOOO

PAZ: XXX XXX ((abriendo y cerrando los brazos)) VAMOS ((indica al equipo a volver a la pizarra) ) vamos ((volviendo a señalar a la pizarra))

ALU: *((el equipo vuelve a la pizarra y comienza a recolocar los carteles $))$

ALU: *((el resto habla, comenta y mirando a la pizarra van diciendo como deberían recolocarse poco a poco van creando un coro que repiten:)) no sabían ((7 veces)) no $\underline{\text { sabían }}$ ((5 veces más con palmadas $))$

-((continúan el coro)) (\&)

PAZ: -sshh [dejar un momento-

LUI: $\quad$ CALLAROS [(iquien tiene boca se equivoca!)

ALU:

PAZ:

equivoca ((abre los brazos))

(\&)-((paran el coro) $)$

(\&)-BUENO=BUENO=oye todo el mundo se

(...)

ALU: ((el equipo continúa trabajando en la frase con la supervisión de PAZ. Después de unos 44 segundos trabajando colocan:))

\section{$L A$ - BOCA - 1 - ZANAHORIA}

((parecen considerar que MULA les sobra o no va en ninguna parte, LUI tiene el cartel de MULA en la mano))

(...)

PAZ: ¿dónde la vas a poner?

LUI: aquí ((coge el cartel de $L A))$ -

PAZ:

lejos y la lees

-deja-déjalo así ((agarra el cartel de $L A))$ y ponte-ponte

ALU: ((el equipo se mueve un paso hacia atrás))

LUI: iy ésta? ((mostrando MULA))

PAZ: ((agarra el cartel)) ¿aquí qué pone?

ALU: ((del equipo)) mula

PAZ: *poneros aquí los tres ((los mueve en grupo hacia atrás))-no=no=no=no no os sentéis (.) Luis mira poneros ahí los tres-shh ((mira a otro alumno)) joye Jesús!=y leer lo que pone a ver si eso tiene sentido (1) a ver (1) ¿qué pone aquí? ((señala $L A)$ ) (1) míralo

ALU: *((el equipo está colocado en línea a dos pasos de los carteles))

LUI: *laa

PAZ: $\quad$ laa [come ((señalando los carteles))

ALU: [boca- ((del equipo))

PAZ: $\quad$-no [la come una zanahoria ((señalando cada cartel))

ALU:

PAZ: [ come zanahoria ((del equipo))

ALU: ((de la clase) ) ¡OY la come!

PAZ: ¿LA COME?

SAL: $\quad$ [((coge el cartel de MULA y lo mira)) XXX ((pregunta algo a PAZ))

PAZ: ¿que (es) está?

ALU: [((de la clase)) LA MULA LA MULA

PAZ: ((mira a la clase y luego a SAL $))$ no se mira a ver

SAL: ((va a los carteles quita $L A$ y coloca $M U L A))$

PAZ: ((ayuda a colocar el cartel)) esta aquí la ponemos ¿y ésta? ((señalando $L A)$ )

LUI: esta XXX ((se adelanta coge el cartel de $L A$ y lo coloca el primero en la frase, tardan unos 8 segundos. Al final queda:)) 


\section{$L A$ - MULA - BOCA - 1 - ZANAHORIA}

53 PAZ: $\quad$ sentaros los tres sentaros ((dirigiéndose al equipo)) (1) a ver-sshh-a ver si esta frase ahora sí tiene sentido a ver ((señalando los carteles)) [la mula come una zanahoria

54 ALU:

((todos a coro $))$

PAZ: ¿tiene sentido? ((mirando al equipo))

ALU: *((varios, del equipo y la clase $))$ síí ahora sííi

PAZ: $\quad *(($ mira al equipo con las manos en la cintura y luego 'agita' a LUI $))$

ALU: $\quad *(($ ríen algunos $))$

PAZ: SI ES QUE ¿SABES LO QUE LES PASÓ? ((dirigiéndose a la clase)) que no leyeron esta palabra ((señalando el cartel de MULA)) dijeron ((moviendo los brazos)) esta la ponemos aquí y no la habíais leído ((negando con la mano)) ¿a que no? ((mirando al equipo))

60 LUI: no

61 PAZ: ¿vees? os hemos pillao bacalao

62 LUI: es que dicía la zanahoria mula ((lo dice levantado de la silla, mirando a la clase y riendo))

63 PAZ: la zanahoria mula come ¿pero eso qué (quiere decir?) ((extrañada))

64 ALU: *((varios risas))

65 CAR: *la zanahoria mula come ((del equipo))

(...)

((hacen la rutina final))

\section{English Translation}

((The group of children has hung on the blackboard:))

MOUTH - CARROT - 1 - THE - MULE

(...)

PAZ: lets see (1) okay (1) let's all read (1)-shh (1) hey by the way ((addressing the group of children)) do you know-this team uh?-this team what it says here? ((pointing at the card $M U L E)$ ) what does it say here?

STU: XXX

PAZ: have you read it? (yes or no?)

STU: no

PAZ: ((lowers her arm)) and then how are you going to [(do the XXX)?

STU: ((Spanish original: pluma cf. 'mula' mule))

[FEATHER ((from the class))

PAZ: $\quad$ lets see what it says here ((covers $L E$ on the card. Spanish original: $L A)$ )

STU: ((the team in a chorus)) feaath-((Spanish original: pluu $))$

PAZ:

LUI:

((from the team)) muu

-((shakes her head "no"))

PAZ: $\quad(($ moves her hand and covers $M U)) \mathrm{mu}$

SAL: $\quad(($ from the team)) le-le muu-l-le ((Spanish original: l-la тии-l-la $)$ )

PAZ: what does it say?

SAL: mule

PAZ: mule (1) well I don't know=let's see then what it says here ((points at the cards)) [eats $\quad$-carrot $=$ one the mule $(\&)$

16 STU: [eats one- =carrot one the mule ((several in a chorus))

17 PAZ: (\&) what's that? ((emphatically, showing incomprehension))

18 STU: ((the whole class laughs)))

19 PAZ: ((pointing at the cards and shaking her hands)) does this make sense? 
20 STU: ((the whole class in a chorus)) NOOO

21 PAZ: XXX XXX ((opening and moving her arms)) C'OMMON ((makes the team go back to the blackboard)) c'ommon ((points at the blackboard again))

22 STU: *((the team goes back to the blackboard and begins to reorganize the cards))

23 STU: *((the rest of the class talks about the cards and progressively creates a chorus)) they didn't know how ((7 times)) they didn't know how

((5 more times clapping $))-(\&)$ original: quien tiene boca se equivoca))

makes mistakes ((opens her arms))

(\&)-((the class stops the chorus))

(...)

(\&)-OKAY=OKAY=hey verybody

STU: ((the team continues working on the phrase with Paz's assistance, after approximately 44 seconds of work they place on the blackboard))

$$
\text { THE - MOUTH - } 1 \text { - CARROT }
$$

((It seems to the team that the card MULE does not go in any place, LUI has the card in his hand))

$$
\text { (...) }
$$

PAZ:

back and read it

STU: ((the team takes a step back))

LUI: and this one? ((showing the card MULE))

PAZ: ((takes the card)) what does it say here?

STU: ((from the team)) mule

PAZ: *the three of you ((moves the team back) $)-n o=$ no=no=no don't sit down (.) Luis look stand here the three of you-shh ((looks at the class)) hey Jesus!=and read what it says there to see if it makes sense (1) let's see (1) what does it say here ((points at THE)) (1) look

STU: ((from the team)) [ $\underline{\text { eats }} \underline{\text { carrot }}$

PAZ: who? ((shrugging her shoulders))

STU: ((from the class)) UPS the eats

PAZ: THE EATS?

SAL: $\quad[(($ takes the card MULE and looks at it)) XXX ((asking PAZ something))

PAZ: (what's) this one?

STU: [THE MULE THE MULE ((from the class))

PAZ: ((looks at SAL and then to the class)) I don't know look and see

SAL: ((goes to the cards on the blackboard takes down $L A$ and puts up MULE))

PAZ: $\quad(($ helps put the card $))$ this one we put here and this one? ((pointing at $T H E)$ )

LUI: this one XXX ((moves forwards, takes the card THE and puts it up in the first position, about 8 seconds working. The result is:)) 
53 PAZ: okay sit down the three of you sit down ((addressing the team)) (1) let's see-sshh-let's see if this phrase does make sense now let's see ((pointing at the cards)) [the mule eats one carrot

54

STU:

((the whole class in a chorus)) [the mule eats one

carrot

PAZ: does it make sense?

STU: $\quad *(($ several from the class and the team $))$ yeees now yeees

PAZ: *((looks at the team with her hands on her waist and the moves forward and 'shakes' LUI))

58 STU: $\quad *(($ some children laugh $))$

59 PAZ: YOU KNOW? YOU KNOW WHAT HAPPENED?! ((addressing the class)) that they didn't read this word ((points at MULE)) they said ((moving her arms)) this one we put it here and you hadn't read it ((denying with her hand)) right? ((looks at the team))

60 LUI: no

$61 \quad$ PAZ: $\quad$ see? we caught you codfish ((Spanish original: os hemos pillao bacalo))

62 LUI: because it said the carrot mule ((getting up from the chair and turning around to address the rest of the class))

63 PAZ: the carrot mule eats but what's (does that mean)? ((surprised))

64 STU: *((several laugh))

65 CAR: *the carrot mule eats ((from the team))

(...)

((they go on to do the final routines))

The transcript, which in total comprises about four minutes of classroom interaction, reflects the complex social moves the students and the teacher make during this multi-step problem solving sequence. Schematically, it can be argued that the episode experiences successive transformations in its key. These keyings and re-keyings are achieved through specific actions by participants; actions that can be both verbal and non-verbal and are almost always part of a clearly visible embodied stance (Goodwin 1998), a set of coordinated body movements through which participants contextualize the way their actions and verbal behavior should be interpreted. These contextualization moves are explicitly designed to modulate the face demands that emerge during the episode.

The sequence begins with a suspicion on the part of the team of students that the sentence they propose is not fully correct. This expectation is confirmed early by the teacher when she focuses the task not on reading the full sentence but on decoding a single card within the sentence (line 1). This is a side-move from the routine procedure that signals the problematic nature of some part of the answer - a part that the teacher herself identifies. Since none of the members of the team are able to answer the question, Paz, the teacher, directly asks the children if they have read the card and the children answer 'no' (lines 3-4). This exchange crystallizes the first face threatening episode in the event because the team aggravates its position through two moves. First, the students fail to solve the task correctly which they supposedly should be able to do given that: (a) the rest of their class-mates had been able to do so and, (b) the decoding skills and graphemes involved in the target word had been introduced numerous times in previous sessions. Second, the team provides an open and unmitigated negative response to the teacher's question (lines 3-4), defying their role expectations by announcing that they did not perform the task that they were assigned. 
Paz reacts promptly to this answer with two moves of her own. First she specifies how not reading the cards (performing the sub-task) inhibits the possibility of completing the full task (line 5). Second, she immediately redirects the activity towards completing this sub-task (i.e. reading the card 'MULA' MULE) (line 7). However, one of the students 'worsens' even further the team's position in the sequence when the decoding sub-routine begins (line 8). Instead of decoding independently the word in the card he recycles a response that an unidentified student unofficially but audibly provided previously (line 6). Using this strategy is considered problematic per se, since the children are expected to solve problems and provide answers based on their own resources, but turns out to be especially inappropriate in this context because the unofficial answer is in fact incorrect (thus it becomes clear that the student is performing a mock decoding). The teacher's response, even though limited to a quick head shake (line 9) is immediate and unambiguous, and is reacted to by another student in the team, Luis, who provides a correct reading of the first syllable of the word (line 10). After this, Salma, another child in the team, collaborates in the completion of the decoding and provides a full and correct reading of the word card (lines 12-14).

Once the sub-task has been solved, the teacher considers that it should be possible to read the full sentence as it has been hung by the team of students. This reading proceeds as a complete Initiation-Response-Evaluation Sequence (IRE Sequence) (Mehan 1978) (line 15: Initiation, line 16: Response, line 17: Evaluation). The evaluation turn, on the hands of the teacher, is another potential turning point in the face needs of the group given the succession of events that have taken place so far. Tacitly but quite obviously Paz, the class and the team are aware that the initial answer is wrong. Further, in solving the first sub-task, the team of students has made two clear moves to aggravate their position in relation to the task and the assessment their peers and the teacher can make. In short, they are in a highly face threatening situation and the key of the episode is becoming quite serious (keyed especially by Paz in the actions of lines 5 and 9). Under these circumstances, the teacher has a number of alternatives which, in turn, lead to different resolutions of the sequence and the social arrangement of the event. One option is to continue the sequence in the same key and provide a negative evaluation that might even escalate the unpleasant nature of the episode. A second possibility is to introduce any number of mitigating devices that, while signaling the incorrect status of the response, downplay the threatening nature of the teacher's action. Finally, the teacher may opt to radically shift the key and contextualization of the sequence so far.

It is the last option that is pursued: The evaluation move (line 17) is presented with an emphatic intonation clearly marking her lack of comprehension. Further, the terms of the evaluation are semantically rather neutral (¿qué es esto? what's that?) in opposition to other evaluative devices frequent in classrooms (e.g. yes / no, right / wrong, good / try again) - although its paralinguistic contextualization is not ambiguous at all. The reaction of the class to this utterance is immediate with the children bursting into laughter. In short, the teacher (and the class ratifies it) re-keys the event from a face threatening and serious episode to a humorous situation which opens a new set of possibilities. The material used to create humor exploits a basic linguistic incongruence (Beeman 1999) by forming a senseless and disordered sentence. The utterance, although rudimentary in contrast to other formats, can be seen as a form of verbal play and a 
metasyntactic operation (Ely and McCabe 1994; Gombert 1992). However, the coordinated play that takes place immediately after the teacher's move is not simple at all. Using Goffman's (1981) dramaturgical metaphor we can think of the teacher, the team and the rest of the class as engaging in a fiction script with three specified roles. One part is played by the 'team', who has produced an incongruent material by arranging incorrectly certain pieces. A second part is played by a 'supervisor', the teacher, who identifies this incongruence, despairs with it and demands that the material be rearranged - stance that is embodied through her arm movements and pointing at the blackboard (line 21). Finally, a third part is played by the 'audience', the rest of the class, who in this case participates improvising a chorus line - which semantically is an open negative evaluation of the children's competence ('¡no sabian!' they didn't know how! $)^{4}$ (line 23). The following video-captured images (2-3) show the teacher's contextualizing non-verbal behavior at the beginning of this routine, just after she has provided her verbal evaluation (line 21 in the transcript). The first photograph shows Paz shaking her arms and moving away from the blackboard (indicating the incorrectness of the phrase). The second photograph shows Paz stretching out her arm and pointing to the black board inviting the group of children to correct the sentence:

(2) Video-capture of the teacher rejecting the phrase (line 21)

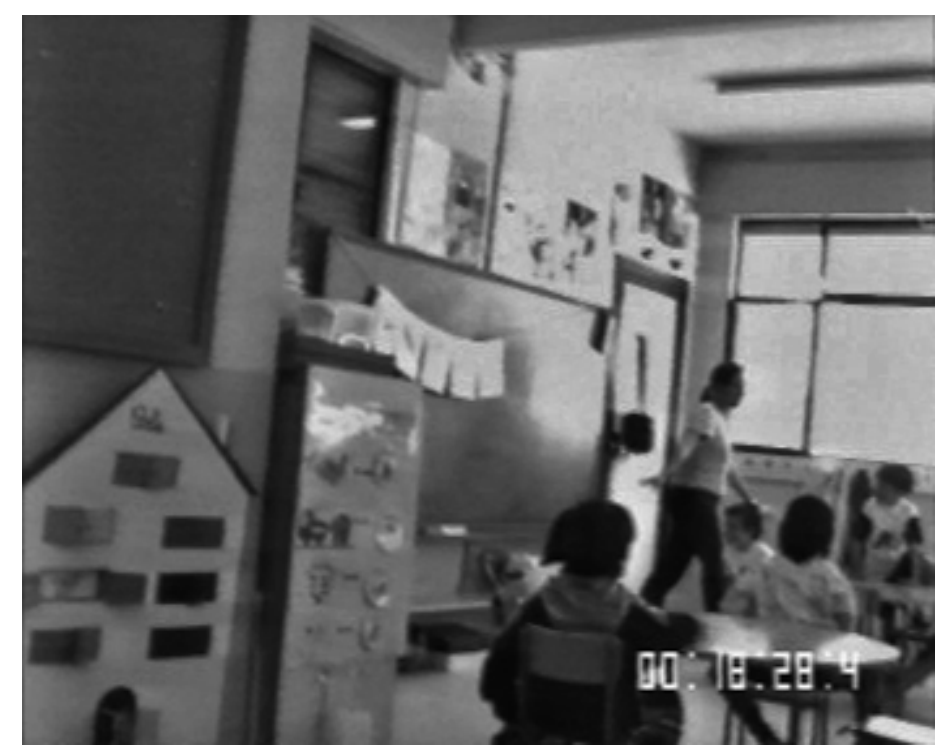

(3) Video-capture of the teacher inviting the students to correct the phrase (line 21)

${ }^{4}$ This distribution of roles is reminiscent of several 'clown shows' in which, within a group of actor-clowns there is a clown who is always causing different types of commotion, another clown who despairs with his or her companion's actions while the audience participates in a number of ways. Further, this script was often used by a group of four clowns who for many years appeared on Spanish TV and was extremely popular among Spanish children and society. 


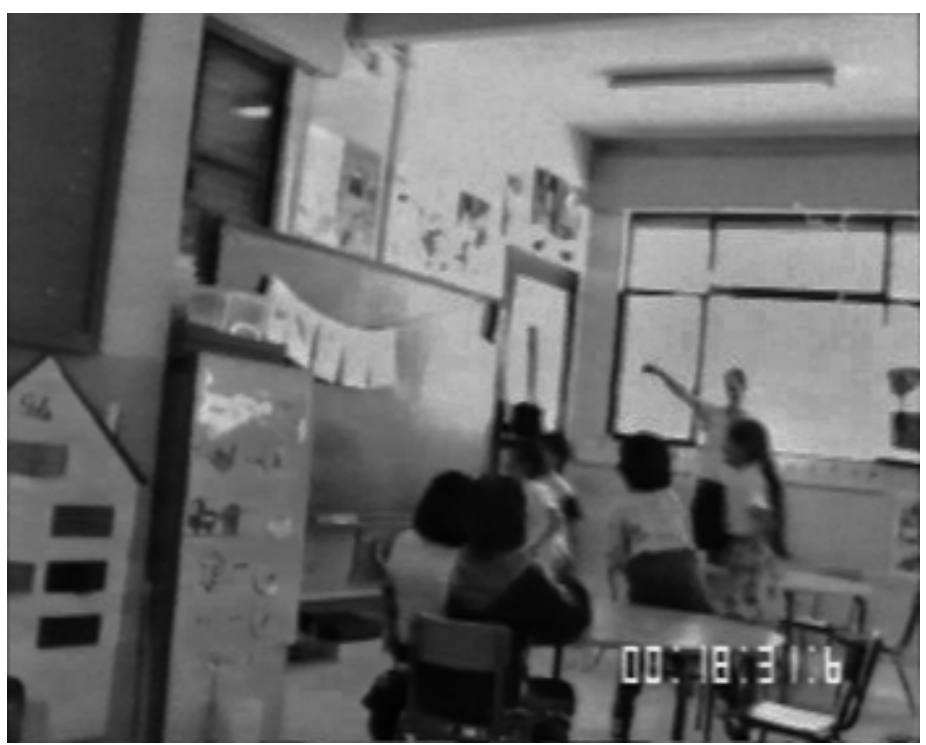

The repetition of the chorus (line 23) has an interesting illocutionary force. While it begins contributing to the humorous nature of the ongoing activity, its recurrence, especially when the chorus is complemented with hand clapping, is progressively perceived negatively by the members of the team. This change in contextualization is made explicit by Luis who in line 25 turns around and emphatically asks his peers to abort their chorus - request that is taken up by the students who finish singing at this point (line 26). Luis' request is relevant because it is accompanied by a frequently used maxim in the classroom ('quien tiene boca se equivoca' who has a mouth makes mistakes) that is explicitly designed to foster participation in instructional events by embracing the belief that it is better to answer and participate, even if the answer is wrong, than not to say anything. In other words, it is a face saving device in instructional events and may be also used to downplay participant's individual agency in the outcome of certain actions and situations (Poveda 2001). Paz recycles Luis' use of the maxim and ratifies the role it is playing in the rekeying of the sequence back to its humorous (or at least less threatening) frame (line 27).

Lines 28-52 capture the larger sequence in which the original phrase is reorganized to build the final and correct sentence. The main component in this process is the teacher scaffolding the team's problem-solving by guiding the children through each successive step of task. However, this aspect of the event is not central to the topic of this paper and will not be further discussed here. What is important to point out is that this sub-task takes place in a relaxed key much closer to the rekeying that occurred with Paz's move in line 17 than with the opening of the episode or the changes associated with the reiteration of the chorus in the second part of line 23 . This is illustrated in the sequence that unfolds when the second version of the phrase, still incorrect, is read by the group. In a simplified format, the IRE sequence contained between lines 36-46 emulates the sequence surrounding the reading of the first sentence: A non-grammatical sentence is read (lines 41-42) and its humorous nature is made explicit by repeating emphatically the incongruent component (lines 44-45). In this case, the incongruence is limited to the omission of one word, the subject (MULE), which is 
finally introduced in the right place producing the correct sentence (line 52). Construing this exchange as humorous is possible given the previous episode (lines 15-18), where each component of the humorous script unfolded completely. For this second occasion, the original IRE sequence is a shared experience that can be recovered by the group to create humor by reproducing the framing of the original episode.

The final reading and evaluation of the sentence (lines 53-65) continues the humorous frame of the episode. However, it is also fundamental in providing the final key in which the full segment should be interpreted, since the framing of the closing sequence feedbacks on the full episode (cf. Bauman 1986; Sacks 1989). First, the teacher makes explicit what the main failure on the part of the team was and how this caused the total set of problems throughout the segment (line 59). In this sense, it deals with the same materials and problems presented at the very beginning of the episode (lines 1-16), however it does so in a radically different key. This is clearly contextualized by the verbal and non-verbal moves that bracket Paz's central appraisal (lines 57- [59] - 61). In line 57 she playfully shakes Luis, expressing her despair at the team for not displaying a competence she and the students 'agreed' the team should have by now. In line $61 \mathrm{Paz}$ introduces another frequently used rhymed maxim ('os hemos pillao bacalao' we caught you codfish) used precisely to assess mistakes in a humorous key. More elaborate is Luis' final reformulation of the team's own actions: He stands up, turns around and addressing his peers states they put the carrot mule ('la zanahoria $m u l a^{\prime}$ ). With this announcement he seems to suggest that they "deliberately" produced an incongruent sentence to precipitate the playful episode they have just been engaged in (note that neither Luis' sentence nor Carlos's recycling, line 65, correspond to any of the two incongruent phrases built earlier - a variation that does not affect its pragmatic goals). This interpretation is ratified by Paz, who reintroduces precisely her original punch-line (line 63) reinforcing the view that this was indeed a turning point, and Carlos, who repeats the nonsense sentence (line 65).

(4) Video-capture of the teacher playfully chastising the group (line 57)

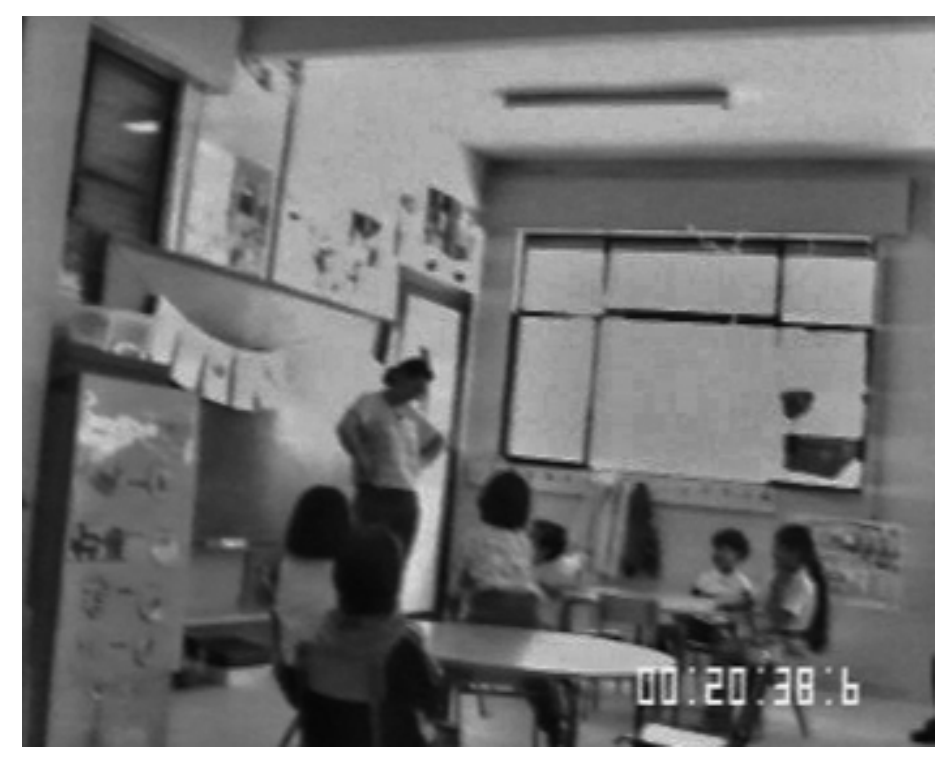

(5) Video-capture of the teacher shaking Luis' head (line 57) 


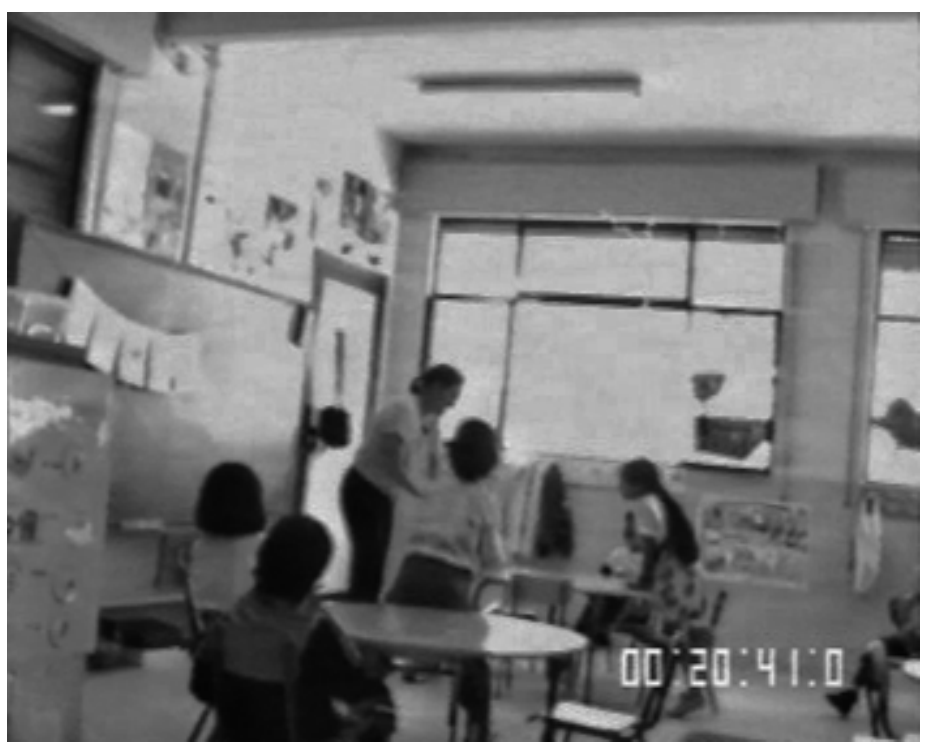

In short, Luis seems to suggest to his classmates that what initially appeared to be an incompetent reading in the word train (and therefore could contribute to a negative portrait of themselves as students), was in fact a deliberate action designed to precipitate the nonsense and humorous play they have been engaged in for the last few minutes - a suggestion that portrays them as quite skillful in certain language activities.

The video-captures (4-5) show the teacher's movements in line 57: First, she puts her hand on her waists pretending to look disapprovingly at Luis and then she playfully shakes his head.

The following graph (6) summarizes the successive contextualizations and rekeyings that take place during this episode. The positive pole indicates a less facethreatening context and a higher humorous key, while the negative pole indicates a higher face-threatening context and a more serious key.

(6) Keying during the fragment of the word train

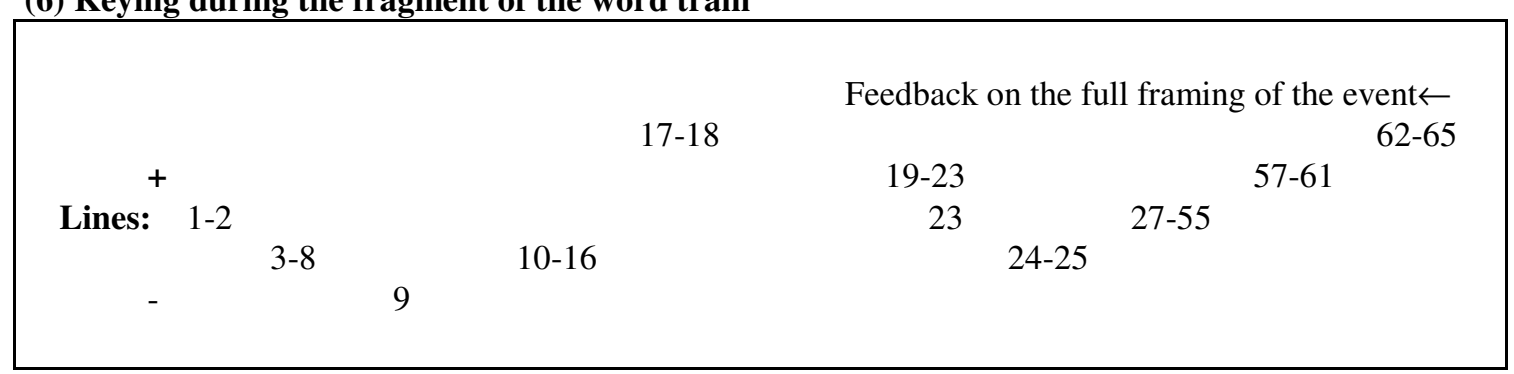

This graphic representation, although not intended to reflect precise quantifiable magnitudes, attempts to capture the complex successive transformations that occur in even relatively short episodes of classroom interaction. Creating and interpreting these kinds of outcomes in the word train requires sophisticated social, linguistic and metalinguistic skills on the part of the children. Some of the broader implications that 
these findings might have for our understanding of classroom discourse are discussed in the conclusions.

\section{Conclusions}

In the word train children are asked to manipulate language in a certain way. Language is also the instrument used to perform this manipulation. This is what makes the event metalinguistic: Language and several internal components of its system are both the medium and the goal of the instructional activity. Curriculum developers and teachers do consider events such as the word train to be activities specifically designed to foster these skills. However, in their formal abstractions of the tasks only a part of the metalinguistic processes taking place are considered. The metasyntactic problems involved in word reordering are clearly specified. The metamorphological adjustments required to retain agreement among words are also considered, especially in a morphologically rich language like Spanish. In contrast, the multiple semantic relations that might exist between drawings, their lexical label and final referent are not fully foreseen $^{5}$ and the occasions for verbal play that this activity may provide are not contemplated at all (e.g. Monfort and Juárez 1996).

For some time now classrooms have been considered spaces in which improvisation has an important role (Erickson 1982) and characterizations of expert teaching incorporate the capacity to situationally adapt classroom scripts and build activity around the shared history of students and teachers (Borko and Putnam 1996). However, these conceptions of teaching have not considered the process by which the emergent and improvised goals of actors become, in fact, their central preoccupation. The analysis of the fragment in this article has attempted to illustrate this transformation by showing how an initially well-scripted activity around relatively constrained materials and curricular contents turns into an event in which verbal play is used creatively to construct and reconstruct complex social identities and alignments.

The physical materials (cards, drawings, rambled sentences) involved in the task allow for these transformations but the outcomes are only possible through the shared social interpretations of the teacher and the children. These shared interpretations are the result of a continued relationship that permits certain social and affective expectations to be incorporated into classroom interaction and allows for improvisation in classroom routines. This micro-historical perspective on classroom life has not been fully pursued in existing research (cf. Rockwell 1999). Studies have documented how children's discourse progresses over a school year (e.g. Kantor et al. 1992) or how teacher's communicative cues to maintain activity are displayed and internalized (e.g. DorrBremme 1990); however, it is less frequent to stress the flexible co-constructions that are possible through shared common experience.

5 For example, the sentence Juan drinks water is represented with the cards: BOY - MOUTH (human mouth as in Fragment 1) - GLASS OF WATER. But these same cards may be used in sentences in which the agent is not human, as the example analyzed in the fragment or sentences such as The elephant drinks water (THE -ELEPHANT - HUMAN MOUTH - GLASS OF WATER). These later uses may be seen as second order associations that cause the children to produce more errors 
As explained in the introduction to the event, the episode I have examined took place towards the end of the school year. By this time the group had a consolidated shared history and a clear knowledge of classroom routines. The selected episode has also many traits that identify it as 'advanced', such as the elaborate group participation structure and the introduction of conventional spelling in the curricular materials. Yet, the previous analysis has attempted to show how accumulated group experience is also reflected in more subtle processes by which participants build and improvise social games based on their understanding of the identities and needs of each class member (teacher of students or peers among themselves). Language use and verbal play are privileged occasions for witnessing the consequences of this group history. As seen above, prosodic devices, lexical choices and even complete statements have a crucial role in the construal of the social event. The microanalytic approach of this paper allows us to disentangle part of this process and bring into clear awareness actions that participants themselves take for granted and do not make explicit but which are fundamental to understanding the identities they have built in the classroom.

\section{References}

Ashkenazi, O., \& D. Ravid (1998) Children's understanding of linguistic humour: An aspect of metalinguistic awareness. Cahiers de Psychologie Cognitive/Current Psychology of Cognition 17.2: 367387.

Bauman, R. (1977) Verbal art as performance. Prospect Heights: Waveland Press

Bauman, R. (1986) Story, performance, and event: Contextual studies of oral narrative. Cambridge: Cambridge University Press.

Beemam, W.O. (1999) Humor. Journal of Linguistic Anthropology 9.1-2: 103-106.

Borko, H., \& R. Putnam (1996) Learning to teach. In D. Berliner \& R. Calfee (eds.), Handbook of educational psychology. New York: Macmillan, pp. 673-708.

Brown, P., \& S. Levinson (1987) Politeness: Some universals in language use. Cambridge: Cambridge University Press.

Cazden, C. (1988) Classroom discourse: The language of teaching and learning. Portsmouth: Heinemann.

Cazden, C. (1992) Whole language plus: Essays on literacy in the United States and New Zealand. New York: Teachers College Press.

Corsaro, W. (1994) Discussion, debate and friendship processes: Peer discourse in U.S. and Italian nursery schools. Sociology of Education 67.1: 1-26.

Dorr-Bremme, D. (1990) Contextualization cues in the classroom: Discourse regulation and social control functions. Language in Society 19: 379-402.

Ely, R., \& A. McCabe (1994) The language play of kindergarten children. First language 14: 19-35. 
Erickson, F. (1982) Classroom discourse as improvisation: Relationship between academic task structure and social participation structure in lessons. In L.C. Wilkinson (ed.), Communicating in the classroom. New York: Academic Press, pp. 153-181.

Goffman, E. (1967) Interaction ritual. Garden City: Doubleday.

Goffman, E. (1981) Forms of talk. Philadelphia: University of Pennsylvania Press.

Gombert, J. (1992) Metalinguistic development. New York: Harvester/Wheatsheaf.

Goodwin, M. (1998) Games of stance: Conflict and footing in hopscotch. In S. Hoyle \& C. Temple (eds.), Kids talk: Strategic language use in later childhood. New York: Oxford University Press, pp. 2346.

Gumperz, J. (1992) Contextualization and understanding. In A. Duranti \& C. Goodwin (eds.), Rethinking context: Language as an interactive phenomenon. New York: Cambridge University Press, pp. 229-252.

Hymes, D. (1974) Foundations in sociolinguistics: An ethnographic approach. Philadelphia: University of Pennsylvania Press.

Kantor, R; J. Green, M. Bradley, \& L. Lin (1992) The construction of schooled discourse repertories: An interactional sociolinguistic perspective on learning to talk in preschool. Linguistics and Education 4: 131172.

Karmiloff-Smith, A. (1992) Beyond modularity: A developmental perspective on cognitive science. Cambridge: MIT Press.

Kirschenblatt-Gimblett, B. (1979) Speech play and verbal art. In B. Sutton-Smith (ed.), Play and learning. New York: Gardner Press, pp. 219-238.

Kotthoff, H. (1995) Oral performance in interactional sociolinguistics: Humorous stories among friends. Toegepaste Taalwetenschap in Artikelen 52: 23-55.

Kotthoff, H. (1998) Irony, quotation and other forms of staged intertextuality: Double or contrastive perspectivation in conversation. InList: Interaction and Linguistic Structures 5 (http://www.ling.unikonstanz.de/inlist).

Kotthoff, H. (1999) Coherent keying in conversational humour: Contextualising joint fictionalisation. In W. Bublitz, U. Lenk \& E. Ventola (eds.), Coherence in spoken and written discourse. Amsterdam: John Benjamins, pp. 125-150.

McDermott, R. (1977) Social relations as contexts for learning in school. Harvard Educational Review 47: 198-213.

Mehan, H. (1978) Structuring school structure. Harvard educational review 48: 32-64.

Monfort, M., \& A. Juárez (1996) El niño que habla: El lenguaje oral en el preescolar, $6^{a}$ edición. Madrid: CEPE.

Nation, K., \& M. Snowling (2000) Factors influencing syntactic awareness skills in normal readers and poor comprehenders. Applied Psycholinguistics 21: 229-241.

Newman, D; P. Griffin, \& M. Cole (1989) The construction zone: Working for cognitive change in school. Cambridge: Cambridge University Press. 
Osherson, D., \& E. Markman (1975) Language and the ability to evaluate contradictions and tautologies. Cognition 3: 213-226.

Phillips. S. (1972) Participant structures and communicative competence: Warm Spring children in community and classroom. In C. Cazden, V. John \& D. Hymes (eds.), Functions of language in the classroom. New York: Teachers College Press, pp. 370-394.

Piaget, J. (1984) La representación del mundo en el niño, 6 edición. Madrid: Morata.

Poveda, D. (2001) La ronda in a Spanish kindergarten classroom with a cross-cultural comparison to sharing-time in the U.S.A. Anthropology and Education Quarterly 32.3: 301-325.

Rockwell, E. (1999) Recovering history in the study of schooling: From the longue durée to everyday coconstruction. Human Development 42.3: 113-128.

Rohl, M., \& C. Pratt (1995) Phonological awareness, verbal working memory and the acquisition of literacy. Reading and Writing: An Interdisciplinary Journal 7: 327-360.

Sacks, H. (1989) An analysis of the course of a joke's telling in conversation. In R. Bauman \& J. Sherzer (eds.), Explorations in the ethnography of speaking, 2nd edition. Cambridge: Cambridge University Press, pp. 337-357.

Sebastián, M., \& A. Maldonado (1998) La reflexión metalingüística: Algunas cuestiones teóricas y aplicadas. Estudios de Psicología 60: 79-94.

Snow, C; M.S. Burns, \& P. Griffin (eds.) (1998) Preventing reading difficulties in young children. Washington D.C: National Academy Press.

Tsai, M., \& G.E. García (2000) Who's the boss? How communicative competence is defined in a multilingual preschool classroom. Anthropology and Education Quarterly 31.2: 230-252.

Tunmer, W; C. Pratt, \& M. Herriman (eds.) (1984) Metalinguistic awareness in children: Theory, research, and implications. Berlin: Springer-Verlag.

Walker, R., \& C. Adelman (1978) Fresas. In M. Stubbs \& S. Delamont (eds.), Las relaciones profesoralumno. Barcelona: Oikos-Tau, pp. 149-168. 